\title{
Journal of the Minnesota Academy of Science
}

\section{The Classification of Languages}

W. W. Folwell

Follow this and additional works at: https://digitalcommons.morris.umn.edu/jmas

Part of the Language Description and Documentation Commons, and the Typological Linguistics and Linguistic Diversity Commons

\section{Recommended Citation}

Folwell, W. W. (1881). The Classification of Languages. Journal of the Minnesota Academy of Science, Vol. 2 No.3, 143-145.

Retrieved from https://digitalcommons.morris.umn.edu/jmas/vol2/iss3/9

This Article is brought to you for free and open access by the Journals at University of Minnesota Morris Digital Well. It has been accepted for inclusion in Journal of the Minnesota Academy of Science by an authorized editor of University of Minnesota Morris Digital Well. For more information, please contact skulann@morris.umn.edu. 
"The President explained, before the reading of Pres. Folwell's paper, that having a short conversation wit' him on the subject a day or two ago, he had solicited of Mr. Folwell a brlef statement in manacript of Rome of the principles which he had stated, bearing on the elasaification and comparison of langunges, and that this paper is the result, as a contribution to the investigation of $\mathrm{Mr}$. Williams.]

\section{THE CLASSIFICATION OF LANGUAGES.}

\section{BY PRESIDENT FOLWELL-UNIVERSITY OF MINNESOTA.}

This problem has received a larger share of attention at the hands of philologists than its unscientific importance would demand. The wish is often father to the thought. The strong desire of such investigators as Chevalier Bunsen to throw the weight of comparative philology on the side of the genetic unity of the human race, unconsciously influenced him and others to immensely overwork the philological argument. While it is clear that the identity of speech is not conclusive as to identity of nationality, it must be admitted that likeness of language goes a long way as a probable argument. There has been going on for some time a vigorous reaction against the free and easy philologizing of the preceding generation. The more eminent writers of the present day are very modest and disclaim their ability in the existing state of their science, to contribute anything more than a probable argument, in favor of the unity of the race. The desire to do so is strong in many instances, but it is not now prudent for men of science to take the risk of reaping "excessive returns of conjecture from a limited seeding of facts."

In other cases the need of demonstrating the physiological unity of the race does not seem so essential as it formerly did.

The present attitude of those philologizers who are entitled to be heard in the general congress of scientific men, is one of suspense. They admit that they have not the knowl- 
edge sufficient to warrant them in any dogmatic statements. Philology asks for more time and more light before taking position for or against the unity of the race.

Futile as the labors of philolgers have been in regard to the solution of this problem, nevertheless in the course of them, great incidental gains have been made.

The object of this brief paper is to call attention to one of them-that of the true principle of classification of languages.

The discovery of Sir Wm. Jones and his co-laborers, near the close of the last century, of the Sanscrit books, marks the birth of modern philology.

The labors of their predecessors had been immense. One can at this time only marval at the diligence which produced such works as the Mithridates of Adelung and Vater, in which the versions of the Lord's prayer in 500 languages and dialects are collected and analyzed.

The principle which vitiated and has rendered almost valueless their researches, is that the attempt was made to classify languages solely upon icrbal resemblances; a method analagous to some of the early attempts at natural history classification. The writers refered to are sometimes spoken of as the "Lexical School" of philologists. The discovery of a better method was an incident of the importation of the Sancrit books to England, whence they became known to the Germans.

In 1 Sox Frederic Schlegel published his " Essay on the Language and Philosuphy of the Indians," a production long since superseded so far as the information in general is conccrned. But all the later investigators are indebted to Schlegel for the clear announcement of a principle faintly indicated by Sir Wm. Jones, that "correspondence in the grammatical structure of different languages proves their identity beyond any other kind of resemblance." 
Grammațical structure, therefore, is the grand test of relationship in languages. Verbal resemblance is not, and is not to be, ignored, but it is secondary and subordinate. As a single example, take the Semitic languages, in which the principle of word formation by interior vowel changes is so conspicuous.

A careful application of the rules of grammatical morphology and of verbal resemblances may be expected to guide to sound results. The dependence on mere verbal resemblances was proved unsafe fifty years ago. One or two reasons may be briefly suggested why languages of distinct families may contain similar words. It is agreed that the imitative process of word formation is one of the most universal and active in the development of speech. The primitive man heard the voices of nature, the buzzing, humming, splashing, rushing, tumbling, etc., and imitated them vocally. As these sounds are universal, men the most widely separated geographically may have developed similar vocables, the grammatical structure of the respective languages remaining utterly unlike.

Again, it has been found that pronouns furnish a great many cases of verbal resemblances among languages of very different families. A probable explanation of this circumstance is the theory that pronominal roots were originally formed on the basis of manual gestures. In the sign language the speaker points to himself to indicate the first person, from him self to indicate the second or third person. The consonants $m$ and $k$ are very prominent in first personal pronouns, and such consonants as $t$ and $y$ arc conspicuous in those of the second and third persons. It is therefore probable that any newly discovered language will furnish pronominal forms similar to those already known.

It is, of course, obvious that mere chance would account for a certain manner of verbal resemblances. 